\title{
Unexpected temporal localization of tuberculosis verrucosa cutis
}

Ereğli State Hospital, Clinic of Dermatology, Konya, Turkey

*Necmettin Erbakan University Meram Faculty of Medicine Hospital, Clinic of Dermatology; **Clinic of Pathology, Konya, Turkey

\begin{abstract}
Clinical forms of cutaneous tuberculosis (TB) which is a chronic granulomatous disease, varies by the route of entry into the body, the number of bacilli, its virulence and the immunological response of the body. TB verrucosa cutis (TBVC) occurs in patients who have previously been affected by tuberculosis bacilli with healthy immunity. A 68-year-old male patient was referred to our dermatology outpatient clinic from an external dermatology center with complaint of verrucous plaques on the left temporal region, persisting for two months. After a diagnosis of wart and seborrheic keratosis, cryosurgery and destructive procedures were applied to the lesions of the patient many times. Histopathological examination revealed granulomatous textures classified by infiltration of inflammatory cells around the keratin plugs and giant multinuclear cells in the epithelium sublayer, and positive staining with CD68 was detected in immunohistochemical examination. The patient was diagnosed with TBVC clinically and histopathologically. At the end of the anti-tuberculosis treatment, the lesions largely regressed with postinflammatory hyperpigmentation.

Herein, we report a case of TBVC with unusual localization, which was initially misdiagnosed as wart and seborrheic keratosis. This case emphasizes the importance of differential diagnosis.

Keywords: Cutaneous tuberculosis, tuberculosis verrucosa cutis, cryosurgery

\section{Öz}

Kronik granülomatöz bir hastalık olan deri tüberkülozu, giriş yoluna, vücudun immünolojik yanıına, basil sayısına ve virülansa bağlı olarak çeşitli klinik formlarda ortaya çıkabilir. Tüberkülozis verrukoza kutis daha önce tüberküloz ile karşılaşmış olgularda ortaya çıkar. Altmış sekiz yaşında erkek olgu iki aydır sol temporal bölgesinde bulunan verrüköz plak şikayetiyle başvurdu. Hikayesinde, dış merkezlerde lezyonlarına siğil ve seboreik keratoz ön tanıları ile birkaç kez kriyocerrahi uygulanmış olduğu öğrenildi. Lezyonlarından yaptığımız histopatolojik inceleme sonucunda; keratin tıkaçları etrafında enflamatuvar hücreler ve epitelde çok çekirdekli dev hücrelerle karakterize edilen granülomatöz yapılar gözlenmişti. CD68 boyası ile pozitif bir ekspresyon saptandı. Histopatolojik tanı tüberkülozis verrukoza kutis olarak yorumlandı. Anti-tüberküloz tedavisinin sonunda lezyonlar postenflamatuvar hiperpigmentasyon ile büyük ölçüde geriledi. Burada başlangıçta siğil ve seboreik keratoz olarak yanlış tanı konulan tüberkülozis verrukoza kutis olgusunu sıradışı lokalizasyonu ve ayııııı tanııının önemini vurgulamak açısından sunduk. Anahtar Kelimeler: Kutanöz tüberküloz, tüberkülozis verrukoza kutis, kriyocerrahi
\end{abstract}

\section{Introduction}

Clinical forms of cutaneous tuberculosis (TB) which is a chronic granulomatous disease varies by the route of entry into the body, the number of bacilli, virulence and the immunological response of the body ${ }^{1}$. Less than $2 \%$ of all tuberculosis

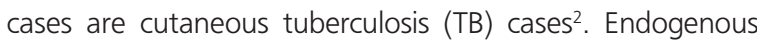

Address for Correspondence/Yazıșma Adresi: Selami Aykut Temiz MD, Ereğli State Hospital, Clinic of Dermatology, Konya, Turkey Phone: +90 3323243403 E-mail: aykutmd42@gmail.com Received/Geliş Tarihi: 06.01.2020 Accepted/Kabul Tarihi: 03.09.2020 ORCID: orcid.org/0000-0003-4878-0045

(C) Copyright 2020 by Turkish Society of Dermatology and Venereology

Turkderm - Turkish Archives of Dermatology and Venereology published by Galenos Yayinevi. 
Endogenous form cutaneous tuberculosis which is the form that the bacillus comes from in another location in the body is the most common clinical form of cutaneous tuberculosis. Endogenous forms of tuberculosis are classified as lupus vulgaris, scrofuloderma, acute miliary tuberculosis, and metastatic tuberculosis abscess. Exogenous forms of cutaneous tuberculosis; TB primer complex and TB verrucosa cutis (TBVC) are less common ${ }^{3}$. TBVC occurs in patients who have previously been affected by tuberculosis bacili but have a healthy immunity?.

Herein, we report a case of TBVC on the left temporal location which was initially misdiagnosed as wart and seborrheic keratosis and emphasized the importance of the unexpected localization and the differential diagnosis.

\section{Case Report}

A 68-year-old male patient was referred to our dermatology outpatient clinic from an external dermatology center with complaint of verrucous plaques placed on the left temporal region, persisting for two months. The dermatological examination revealed painless, firm, verrucous, hyperkeratotic serpiginous plaques on the left temporal region (Figure 1A). With the misdiagnosis of verruca vulgaris and seborrheic keratosis, cryosurgery and destructive procedures were applied to the lesions of the patient many times. A skin biopsy was performed with the prediagnoses of TBVC, verruca vulgaris, lichen simplex chronicus, hypertrophic lichen planus, seborrheic keratosis, blastomycosis, chromomycosis, and sporotrichosis.

The histopathological examination revealed granulomatous textures classified by infiltration of inflammatory cells around the keratin plugs and giant multinuclear cells in the epithelium sublayer (Figure 1B), and a positive staining with CD68 was detected in the immunohistochemical examination. The patient was diagnosed with TBVC clinically and histopathologically. Our case was referred to the department of pulmonary medicine for systemic tuberculosis research. The tuberculosis skin test (also known as the PPD or tuberculin test) was positive with $11 \mathrm{~mm}$. There was no pathology detected in the posteroanterior chest radiography, and pulmonary computed tomography. Primary tuberculosis focus that would lead to lymphomatous or hematogenous spread was not considered.

The family history of the patient was unremarkable for tuberculosis and he had not worked in any occupation that posed a risk of tuberculosis. Antituberculosis treatment (ethambutol $1500 \mathrm{mg} /$ day, isoniazid $300 \mathrm{mg} /$ day, rifampicin $600 \mathrm{mg} /$ day, pyrazinamide $2 \mathrm{gr} /$ day) was ordered. Two months after these combination of drugs, treatment was continued with rifampicin and isoniazid for four months. At the end of the antituberculosis treatment, the lesions largely disappeared

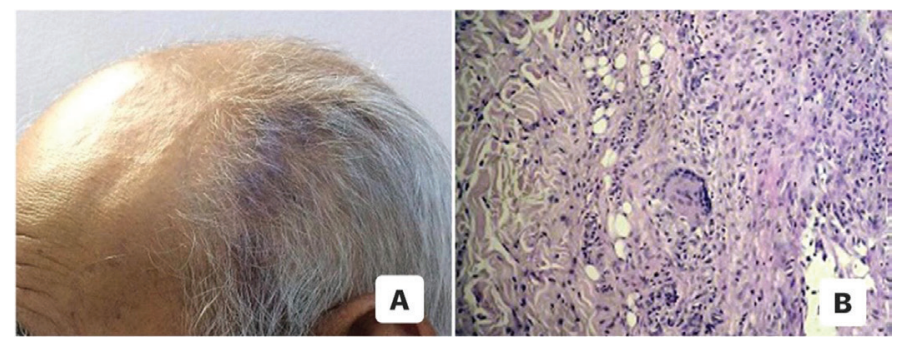

Figure 1. (A) The verrucous plaques seen on the left temporal region, (B) The multinucleated giant cells with periodic acid-schiff stain X 20 with postinflammatory hyperpigmentation (Figure 2). No recurrence was observed in the two-years follow-up of our patient. An informed consent form was obtained from the patient for this case report.

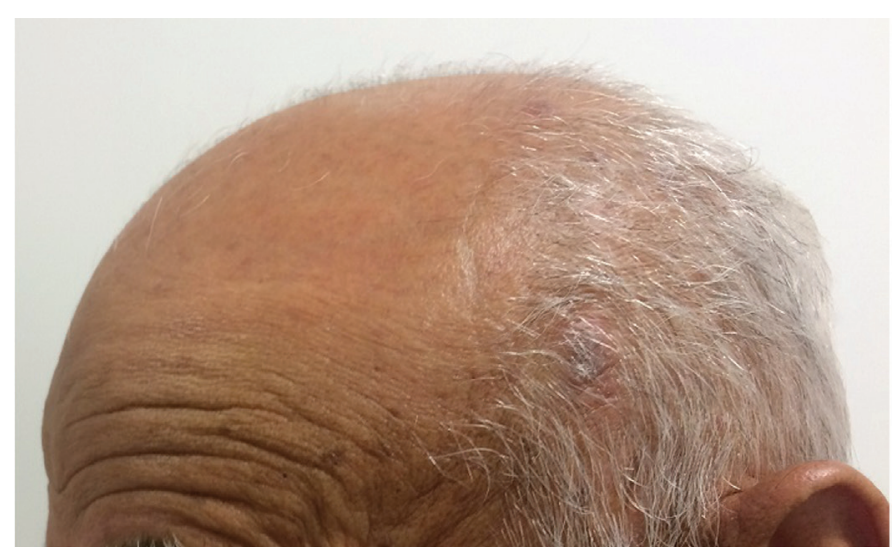

Figure 2. The lesions disappeared by post-inflammatory hyperpigmentation

\section{Discussion}

Tuberculosis is one of the major public health problems around the world ${ }^{4}$. In developed countries, tuberculosis is still important because of the increase in human immunodeficiency virus infection, the increase in malignancy, and the increase in cases receiving immunosuppressive treatment. Tuberculosis is also still important due to malnutrition and poor hygiene conditions in underdeveloped countries ${ }^{5}$.

Cutaneous tuberculosis is observed in about $2 \%$ of all cases of extrapulmonary tuberculosis ${ }^{6}$. The most observed forms of cutaneous tuberculosis are lupus vulgaris and scrofuloderma ${ }^{5}$. TBVC is a rare form of cutaneous tuberculosis, which is caused by exogenous inoculation of the bacillus into the skin through open wounds or abrasions in sensitized persons ${ }^{5}$. In a study published by Sehgal et al. ${ }^{7}$, TBVC was observed in approximately $6 \%$ of all skin tuberculosis involvement. This rate may vary between countries. The lesion of TBVC presents as a small, asymptomatic, indurated wart-like papule with a slender inflammatory border. It slowly grows in a serpiginous style into a verrucous or hyperkeratotic plaque. In untreated cases, the disease runs a prolonged chronic course ${ }^{8}$. In our case, the lesions were seen as firm, verrucous, hyperkeratotic plaques, which were seen on the left temporal area of the head.

The lesions of TBVC are mostly seen on extremities, which are generally areas that are exposed to trauma ${ }^{9}$. In Europe, the affected parts of the body are mostly the hands, but in Eastern countries, the knees, ankles, and buttocks are more often affected. In a study in Turkey by Ünal et al. ${ }^{5}$, all the TBVC lesions were reported on the extremities. In our case, the lesions were interestingly located on the left temporal region.

Paracoccidioidomycosis, leishmaniasis, sporotrichosis, chromomycosis, hypertrophic lichen planus, blastomycosis, atypical mycobacteriosis, verrucous carcinoma, iododerma, seborrheic keratosis, bromoderma, verruca vulgaris, lichen simplex chronicus, keratoacanthoma centrifugum, and pyoderma vegetans should also be considered as the differential diagnosis of TBVC ${ }^{10}$. The diagnosis of TBVC is challenging and requires the correlation of clinical, histological, and laboratory 
findings. In variants of skin tuberculosis, one has to rely on examinations such as histopathology, acid-fast bacilli culture, or polymerase chain reaction (PCR) for confirmatory diagnosis ${ }^{11}$. However, mycobacteria are difficult to see or isolate in culture ${ }^{11}$, and the PCR method results in substantially negative pausibasic forms of skin tuberculosis (such as TBVC). The histopathological findings are characterized by significant pseudoepitheliomatous hyperplasia of the epidermis with giant cells. Granulomatous infiltration is typical in cutaneous histopathology, but caseous necrosis rarely found. Multinuclear giant cells are usually found in the histopathology, as seen in our patient.

Anti-tuberculous treatment regimens for pulmonary tuberculosis are usually sufficient to treat cutaneous tuberculosis because the bacillus burden in cutaneous tuberculosis is much less than that of pulmonary tuberculosis. Furthermore, an anti-TB therapy response may be useful as a diagnostic criterion. In this way, a successful response to treatment should be conducive to making a diagnosis ${ }^{12}$. Cryotherapy, electrocautery, and surgical excision may be used in the treatment of localized lesions in addition to systemic treatment in the form of cutaneous tuberculosis such as scrofuloderma, TBVC, and lupus vulgaris.

TBVC masquerading on the temporal region, to our knowledge, has not been reported until now. Therefore, this deserves reporting in order to highlight the atypical location that TBVC can also be presented with. Herein, we report a case of TBVC, which was initially misdiagnosed as wart and seborrheic keratosis, and emphasized the importance of the unexpected localization and the differential diagnosis.

\section{Conclusion}

TBVC should definitely be considered in the differential diagnosis of verrucous lesions. In particular, the presence of inflammatory purple ring around the lesions, the absence of Auspitz's phenomenon in the lesions, and the unresponsiveness to the wart treatments should be warning signs. Dermatologists and pathologists should be aware of this condition, especially when dealing with verrucous lesions of the skin. TBVC on the temporal region is unexpected and needs to be highlighted to avoid misdiagnosis and incorrect, or delayed treatment.

\section{Ethics}

Informed Consent: An informed consent form was obtained from the patient for this case report.
Peer-review: Externally peer-reviewed.

\section{Authorship Contributions}

Surgical and Medical Practices: S.A.T., I.Ö., M.C.A., Concept: S.A.T., Design: S.A.T., Data Collection or Processing: S.A.T., I.Ö., M.C.A., Analysis or Interpretation S.A.T., I.Ö., A.A., R.D., Literature Search: S.A.T., I.Ö., Writing: S.A.T., I.Ö., A.A., R.D.

Conflict of Interest: No conflict of interest was declared by the authors.

Financial Disclosure: The authors declared that this study has received no financial support.

\section{References}

1. Gawkrodger DJ. Mycobacterial infections. In: Ed. Champion RH, Burton JL, Burns DA, Breathnach SM. Rook Textbook of Dermatology, 6th ed. Oxfrod: Blackwell Science. 1998;1199-200.

2. Baylan O, Arca E, Ozcan A, Kisa O, Albay A, Doganci L: Polymerase chain reaction based detection of Mycobacterium tuberculosis complex in lupus vulgaris: a case report. Int J Tuberc Lung Dis 2004;8:1147-50.

3. Barbagallo J, Tager P, Ingleton R, Hirsch RJ, Weinberg JM: Cutaneous tuberculosis. American journal of clinical dermatology 2002;3:319-28.

4. Utaş S, Güler E, Yılmaz SP: A Case of tuberculosis verrucosa cutis, misdiagnosed and treated as a wart. Türkiye Klinikleri J Med Sci 2012;32:822 6.

5. Ünal I, Özdemir F, Kazandı AC, Alper S, Yazkan F: Cutaneous tuberculosis: A 18 - year retrospective evaluation. Turkderm 2003;37:32-6.

6. Pandhi D, Reddy BSN, Chowdhary S, Khurana N: Cutaneous tuberculosis in Indian children: the importance of screening for involvement of internal organs. J Eur Acad Dermatol Venereol 2004;18:546-51.

7. Sehgal VN, Sehgal R, Bajaj P, et al: Tuberculosis verrucosa cutis (TBVC). J Eur Acad Dermatol Venereol 2000;14:319-21.

8. Gönül M, Gül Ü, Kiliç $A$, Soylu S, Demiriz M, Kubar A: Coexistence of tuberculosis verrucosa cutis with scrofuloderma. Turkish J Med Sci 2008;38:495-9

9. Tappeiner $\mathrm{G}$, Wolff $\mathrm{K}$ : Tuberculosis and other mycobacterial infections. In: Ed. Freedberg IM, Eisen AZ, Wolff K, et al. Fitzpatrick's Dermatology in General Medicine. 6th ed. New York: Mc Graw-Hill; 2003:1936-7.

10. Dias MFRG, Bernardes Filho F, Quaresma MV, Nascimento LVD, Nery JADC, Azulay DR: Update on cutaneous tuberculosis. An Bras Dermatol 2014;89:925-38.

11. Bravo FG, Gotuzzo E: Cutaneous tuberculosis. Clin Dermatol 2007;25:17380.

12. Daye M, Temiz SA, Erayman I, Oltulu P: Primer skin tuberculosis as a sporotricoid in the right arm. Selcuk Med J 2019;35:278-81. 